\title{
International culinary influence on street food: an observatory study
}

\section{Siti Nurhayati Khairatun}

Department of Food Service \& Management, Faculty of Food Science \& Technology, Universiti Putra Malaysia

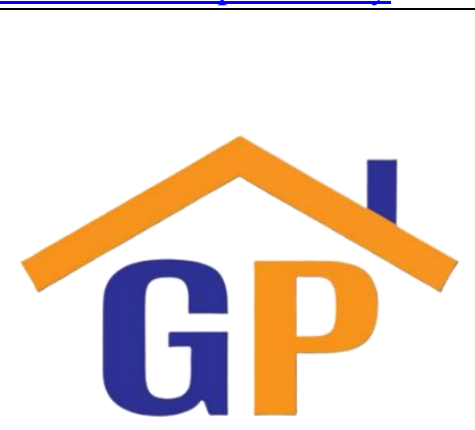

Article History

Received on 9 November 2020

Revised on 2 December 2020

Accepted on 3 December 2020

\begin{abstract}
Purpose: This paper presents a street food profiling of one of the most popular tourist attractions in Melaka, Jonker Street. The main objective of this study is to develop a street food profile of Jonker Street in determining whether local or international culinary influence represents the food sold there.
\end{abstract}

Research methodology: An on-site observation was conducted to investigate the types of food sold and the range of prices offered. A descriptive analysis was completed to characterize street food.

Results: The findings indicated that most of the food sold here represents international and trendy flavor rather than local.

Limitations: This study was self-funded and conducted on the Jonker Street location only. Due to that, no generalization can be derived from the data.

Contribution: This study also provides a baseline reference for the tourism players in outlining strategies toward sustainable tourism relating to local culinary offerings.

Keywords: Culinary tourism, Street food, Observatory study

How to cite: Khairatun, S. N. (2020). International culinary influence on street food: an observatory study. Journal of Sustainable Tourism and Entrepreneurship, 1(3), 179-193.

\section{Introduction}

Around the globe, local street food areas are some of the most visited attractions by tourists. Each country's street food scenes offer their own gastronomy uniqueness, distinct flavors, and creative presentations. In 2017 alone, it was estimated that travelers spent more than US\$186.8 billion on food while traveling (Global Data, 2018). The economic impact is huge because tourists spend approximately $25 \%$ of their total expenditures on food while traveling. According to a survey conducted in 2016, $81 \%$ of respondents have experienced and learned about local culture by consuming food when they visited a destination (World Food Travel Association, 2016). They also believe that by experiencing the local food they would have a better understanding of the local culture. To ensure food tourism as part of sustainable tourism activities, it should respond to the demand and needs of its customers.

Many works of literature investigated street food from consumers' behavior perspectives, the application of regulation and policy, and practices of food safety and hygiene among street food vendors to understand this industry better. Tourists today are seeking local flavor and identity because food tourism has been evolving rapidly recently (Rivera, 2018). However, with advancements in technology, accessibility to wireless networking, and interactive social media that open up communication among the world community, street food is compelled to adapt to the current demands and trends as well.

This paper presents a street food profile gathered and analyzed from data collected through onsite observation made on street food vendors along Jonker Street, Melaka, Malaysia. The profile consists of types of food sold and their range of prices. This paper also argues, contrary to the literature, that street food sold at Jonker Street has adapted to contemporary, international, and trendy flavors rather than preserving its traditions and heritage flavors. 
Note that this study was completed before the COVID-19 pandemic hit the world. Therefore, all data collection process was concluded in normal circumstances. As such, the data gathered were rich and unbiased to any standard operating procedures imposed by the authority during the pandemic crisis.

\section{Literature Review}

The integral relationship between food and tourism is indispensable. People travel and enjoy dining at their preferred establishments to seek for ineradicable experiences during their stay at those interesting places. Some people travel for the sole purpose of exploring local dishes that are associated with culture and tradition. This part explains the literature on food tourism, street food, and its current research trend. The selection of Jonker Street as the research setting for data collection is also justified here.

\subsection{Food tourism}

People travel for many purposes including work, business, leisure, study, and dining, to name a few. In the U. S, approximately $25 \%$ of people travel to experience local food and cuisine (the US Travel Association, 2019). A survey conducted by Malaysia Tourism Promotion Board indicated that $13.4 \%$ of tourist expenditures were on food and food was the third top item purchased (82.8\%) after handicraft/souvenir and apparel/clothes (Malaysia Tourism Promotion Board, 2018). Food is a vehicle for inclusion, economic development, and national cohesion (United Nations World Tourism Organization, 2016). The term food tourism is also used in tandem with food travel, culinary tourism, and gastronomic tourism, though they differ in some ways depending on the context referred to. The World Food Travel Association defines food tourism as an act of traveling for a taste of place to get a sense of place (World Food Travel Association, 2019). Food tourism, or gastronomic tourism, is tourism where the primary purpose of traveling is to visit a specific gastronomical region, to seek out producers of food, to visit food festivals, or to explore tastings and any activity relating to food (McGuire, 2017). Food tourism includes activities: cooking with locals; eating at locals' homes, restaurants, street food, tasting workshops of locally made food products; touring farms, fairs or local markets; and taking part during harvesting season (Centre for the Promotions of Imports-European Union, 2019). Studies have found that food tourism affects job opportunities for the locals (Mnguni \& Giampiccoli, 2016), to provide a platform to boost the local economy, to promote innovation and marketing supports (Nwokorie, 2015), and to enhance the competitiveness values of the attraction spots (Rinaldi, 2017). Importantly, food tourism supports the initiatives to preserve local food ingredients and producers such as certification of geographical indicators of tiramisu cheese (Italy), Champagne wine (France), Bario rice (Malaysia), and Kobe beef (Japan). Based on a domain analysis done in research, food tourism consists of five themes: motivation, culture, destination orientation, management and marketing, and authenticity (Ellis, Park, Kim, \& Yeoman, 2018). Thus, food tourism is significantly related to exploring local authentic experiences and cultural elements.

\subsection{Street food}

Food and Agriculture Organization of the United Nations defines street food as ready-to-eat foods and beverages prepared or sold by vendors by the streets (Food and Agriculture Organization of the United Nations, 2016). Due to its easy accessibility, cheaper prices, and abundant choices, it attracts people from low- and middle-class income groups. In many countries, locals normally sell street food, even though the influx of immigrants has changed the culinary landscape of that particular place. Street food contributes to the food tourism experience for tourists because it represents the image of the location (Privitera \& Nesci, 2015). Tourists indulge in street food because they perceive the food as an authentic value that is significantly associated with the local history (Newman \& Dhar, 2014) and ethnic identities (Henderson, 2014). In Malaysia, some streets are popular with their street food and become tourist attractions. Street locations such as Gurney Drive (Penang), Jonker Street (Melaka), Jalan Alor (Kuala Lumpur), to name a few, are listed in many tour guides as a must-go place for their street food. 


\subsection{Jonker street}

Jonker Street, one of the popular tourist attractions in Melaka, is situated along the Chinatown of Melaka. Figure 1 shows a map of Peninsular Malaysia where Melaka is located. This street, also known as Jalan Hang Jebat, offers various interesting places and activities throughout the year. Built during the Dutch occupation in mid of the 19th century, some heritage buildings are the landmarks here including Baba Nyonya's Heritage Museum, Cheng Ho's Cultural Museum, Cheng Hoon Teng Temple, Kampung Kling Mosque, Kampung Hulu Mosque, and Sri Poyyatha Vinayagar Moorthi Temple (Hotel.com, 2019). During the daytime, Jonker Street is occupied with tourists who want to shop and dine at shops and restaurants along with the old buildings. Usually, the street food sold here is only available during the night time on Friday and Saturday evening, for example, from $6 \mathrm{pm}$ to 12 am. A travel blog highlighted numerous must-try street foods such as Chicken Rice Balls, Satay Celup, Nyonya Asam Laksa, Curry Fish Balls, Nyonya Popiah, Fried Quail Eggs, Nyonya Chang, Pie Tee, Cendol Gula Melaka, Egg Tarts and Pineapple Tarts (Dahodwala, 2018). Other examples of local snacks and meals available at Jonker Street food stalls include Apam Balik, Fruit Sticks, Dim Sums, BBQ Giant Scallop, Ice Cream Rolls, Coconut Water Balls, and Sambal Lala (Leong, 2015). It should be noted that most travel blogs described popular local food sold by restauranteurs along Jonker Street rather than the street food sold by the hawkers or stalls. Their reviews on food sold at Jonker Street were restricted to what they had eaten and apparently, those reviews were biased towards local foods only. Apart from a wide array of food offerings, Jonker Street is also a one-stop place to find numerous souvenirs, local hand-made crafts, and customized art crafts for the tourists. It has been said that visiting Melaka is deemed incomplete if the tourists failed to visit Jonker Street. On a different note, the Melaka Historic City Council is a state agency that governs and manages all affairs relating to Jonker Street. Any event to be held in Jonker Street should obtain a special permit issued by the Council. This special permit is to safeguard the security and peaceful environment among visitors and vendors. However, this Council does not regulate the food sold here should be local and authentic. According to government statistics, the total number of tourists' arrival in Melaka was 16.8 million with 11 million domestic travelers and more than 5 million international tourists (Data.gov.my, 2017).

Given the remarkable characteristics as the most visited attraction among the tourists, Jonker Street warrants a study to explore the food offerings available along its street. The lack of literature on street food profiling warrants this study to be conducted at Jonker Street, a heart of tourists' attraction in Melaka. Street food reflects the identity and culture of the local community and the absence of its profiling will cause the local culinary to lose its originality and authenticity. The impact is harmful to the tourists' influx in the future. If the stakeholders fail to address the concern appropriately, the tourist attraction will not be sustainable in the long run. Besides, the COVID-19 crisis has caused tourists to become more selective in choosing worthy places visiting, and value for their money as well as time. As such, preserving the street food identity should be the highlighted agenda by the industry players. 


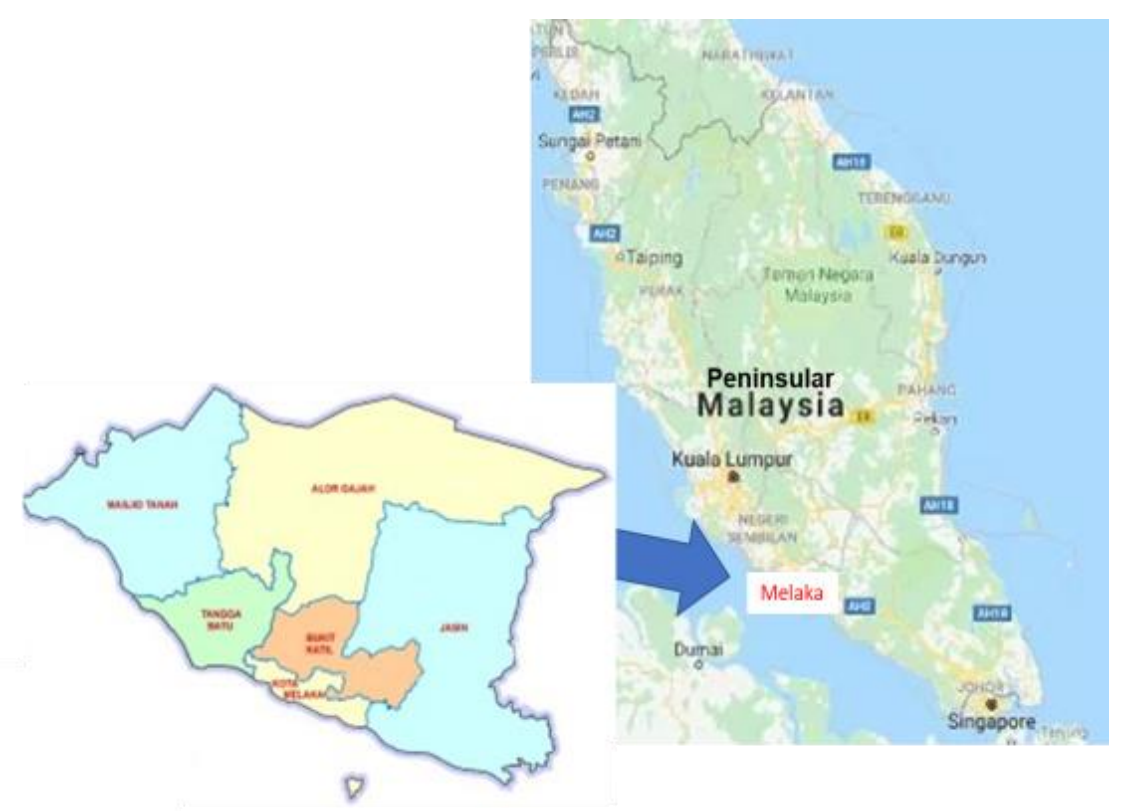

Figure 1: Melaka is located in the south region of Peninsular Malaysia.

\subsection{Current research trend on street food}

Research on street food has gained great attention from researchers around the world. Based on a Google Scholar search with keywords "street food", the recent top 15 articles were focused on the consumers' behaviors, regulations, hygiene, and safety practices of the street food preparation. The ways of street food preparation are evidently not in compliance with food hygiene standards and are always exposed to the risk of food poisoning and contamination (DeWaal \& Rober, 2017). Due to the growing concern of street food safety, many studies have addressed similar issues. Researchers around the world have similar interests in working on hygiene and safety practices related to street food near their places. For instance, some latest research works have been completed in countries such as China (Dai, Zhong, \& Scott, 2019), Bangladesh (Nizame, Alam, Masud, Shoab, Opel, Islam, Luby, \& Unicomb, 2019), Ghana (Ghartey, Adu-Oppong, \& Doku, 2019), Ethiopia (Tadesse, Mitiku, Teklemariam, \& Marami, 2019), and Namibia (Shiningeni, Chimwamurombe, Shilangale, \& Misihairabgwi, 2019) addressing food hygiene, safety and microbial quality found in the street food. One study was completed in Florida, USA relating to regulations and its challenges for street food inspection (Okumus \& Sonmez, 2019). Researchers have investigated various types of establishments selling street food. For example, street food sold in modern urban space (de Santana \& Amparo-Santos, 2019), street food prepared on food truck (Isoni Auad, Cortez Ginani, dos Santos Leandro, Stedefeldt, Habu, Yoshio Nakano, Costa Santos Nunes, \& Puppin Zandonadi, 2019), and street food vending (Letuka, Nkhebenyane, \& Thekisoe, 2019). Most research works were based on food prepared by the roadside and sold to the consumers directly (Ghartey et al., 2019). While some researchers dealt with street food handlers' practices (de Freitas, da Cunha, \& Stedefeldt, 2019; Oliveira, \& de São José, 2019). Research works focused on specific food items sold as street food, including mussels (Kocatepe, Keskin, \& Kaya, 2019) and ready-to-eat beef (Shiningeni et al., 2019). The investigation on nutrition contents in street food was conducted to understand the community's knowledge and their understanding of healthy street food (Hill, Mchiza, Puoane, \& Steyn, 2019). A study on consumer behavior concerning street food consumption was accomplished in Bangladesh (Sarker, 2019). A summary of the latest articles on street food is outlined in Table 1.

Table 1: List of publication on street food

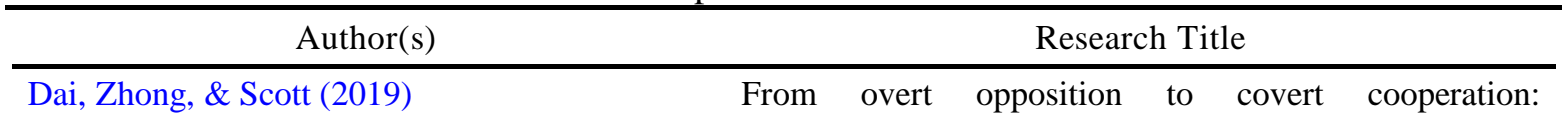


deFreitas, da Cunha, \& Stedefeldt (2019)

deSantana \& Amparo-Santos (2019)

Ghartey, Adu-Oppong, \& Doku (2019)

Hill, Mchiza, Puoane, \& Steyn (2019)

Isoni Auad, Cortez Ginani, dos Santos Leandro, Stedefeldt, Habu, Yoshio Nakano, Costa Santos Nunes, \& Puppin Zandonadi (2019)

Kocatepe, Keskin, \& Kaya (2019)

Letuka, Nkhebenyane, \& Thekisoe (2019)

Nizame, Alam, Masud, Shoab, Opel, Islam, Luby, \& Unicomb (2019)

Okumus \& Sonmez(2019)

Oliveira \& deSão José (2019)

Sarker (2019)

Tadesse, Mitiku, Teklemariam, \& Marami (2019)

Ukenna \& Ayodele(2019)

Shiningeni, Chimwamurombe, Shilangale, \& Misihairabgwi (2019)
Food safety knowledge as gateway to cognitive illusions of food handlers and the different degrees of risk perception

Institutionalization of street food in the modern urban space: Conformations, tensions and conflicts

Personal hygiene practices of street-food-vendors in a rural district in Southern Ghana

Food sold by street food vendors in Cape Town and surrounding areas: A focus on food and nutrition knowledge as well as practices related to food preparation of street-food vendors

Food trucks: Assessment of an evaluation instrument designed for the prevention of foodborne diseases

The effect of frying-the chemical, microbiological, and acrylamide composition of mussels as a street food

Assessment of food safety knowledge, attitudes and practices among street food vendors and consumers' perceptions of street food vending in Maseru Lesotho

Hygiene in restaurants and among street food vendors in Bangladesh

An analysis on current food regulations for and inspection challenges of street food: Case of Florida

Food handling practices and microbial quality in street food

Consumer behavior on street food in Bangladesh

Salmonella and Shigella among asymptomatic street food vendors in the Dire Dawa city, Eastern Ethiopia: Prevalence, antimicrobial susceptibility pattern, and associated factors

Applying the extended theory of planned behavior to predict sustainable street food patronage in a developing economy

Prevalence of pathogenic bacteria in street vended ready-to-eat meats in Windhoek, Namibia

\section{Research methodology}

This study was conducted long before the implementation of lockdown due to the COVID-19 pandemic in Malaysia, which was in July 2019. As such, the tourists crowd at Jonker Street was doing their normal businesses and unrestricted to any standard operating procedures outlined by the authority. The data collection process in this study employed a systematic on-site observational approach. This unobtrusive method is deemed appropriate to use because there is 
no direct involvement between the researcher and the subject observed (Veal, 2017). Five phases of the data collection process were involved in this study: 1) select a tourist location 2) determine the site framework 3) begin on-site observation 4) collect data and 5) analyze data. A flow chart of the data collection process is presented in Figure 2. According to Saldana and Omasta (2017), it is important to outline the objective of the study before deciding on how to conduct the observation.

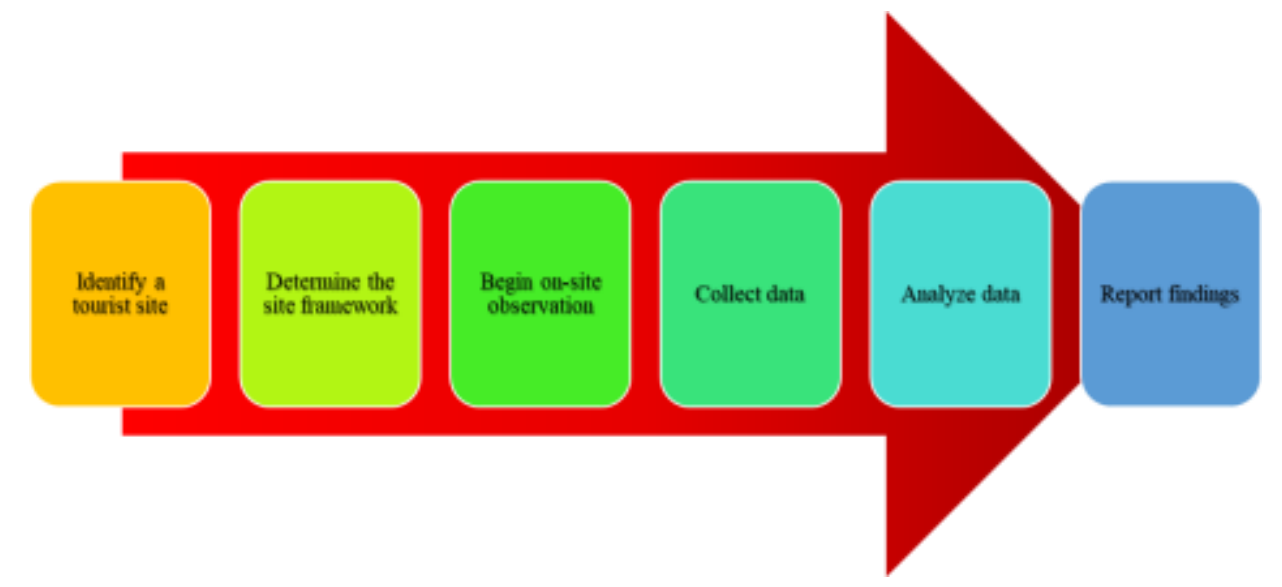

Figure 2: Flowchart of the data collection process

To begin with, this study identified a suitable tourist attraction in Melaka. The selection of Jonker Street as the main location for this study was done based on recommendations from two popular online travel advisory and guide providers (TripAdvisor, 2019; Traveloka, 2018). These travel advisories placed Jonker Street as one of the top ten interesting places to visit in Melaka. As Jonker Street offers both food and non-food items, the sample selected for this study was restricted to the street food vendors.

In the second phase, the tourist site was measured and marked. The purpose of marking was to ensure the observation process would be completed within the marked area. All food stalls were situated within the marked area. Beyond the marked area, no stall could be found at all. A Google map was referenced to assist in the marking process. Jonker Street, composed of several blocks of shop units, was built during Dutch colonization in the 17th century. Multi-themed restaurants, bars and pubs, souvenirs and handicraft shops, as well as entertainment outlets, could be found along with those blocks. From the eye-level angle, the vendors' stall arrangement was on both sides of the street and this layout has caused the street overcrowded with visitors. The onsite observation began at point A and ended at the same point. Figure 3 shows Jonker Street on a Google map marked with red and the observation starting-exiting point is marked A. The entire observation process was completed within approximately 3 hours in one visit, i.e., 7 pm until 10 $\mathrm{pm}$. The day selected was in the weekend evening. No festival was held during the data collection process. 


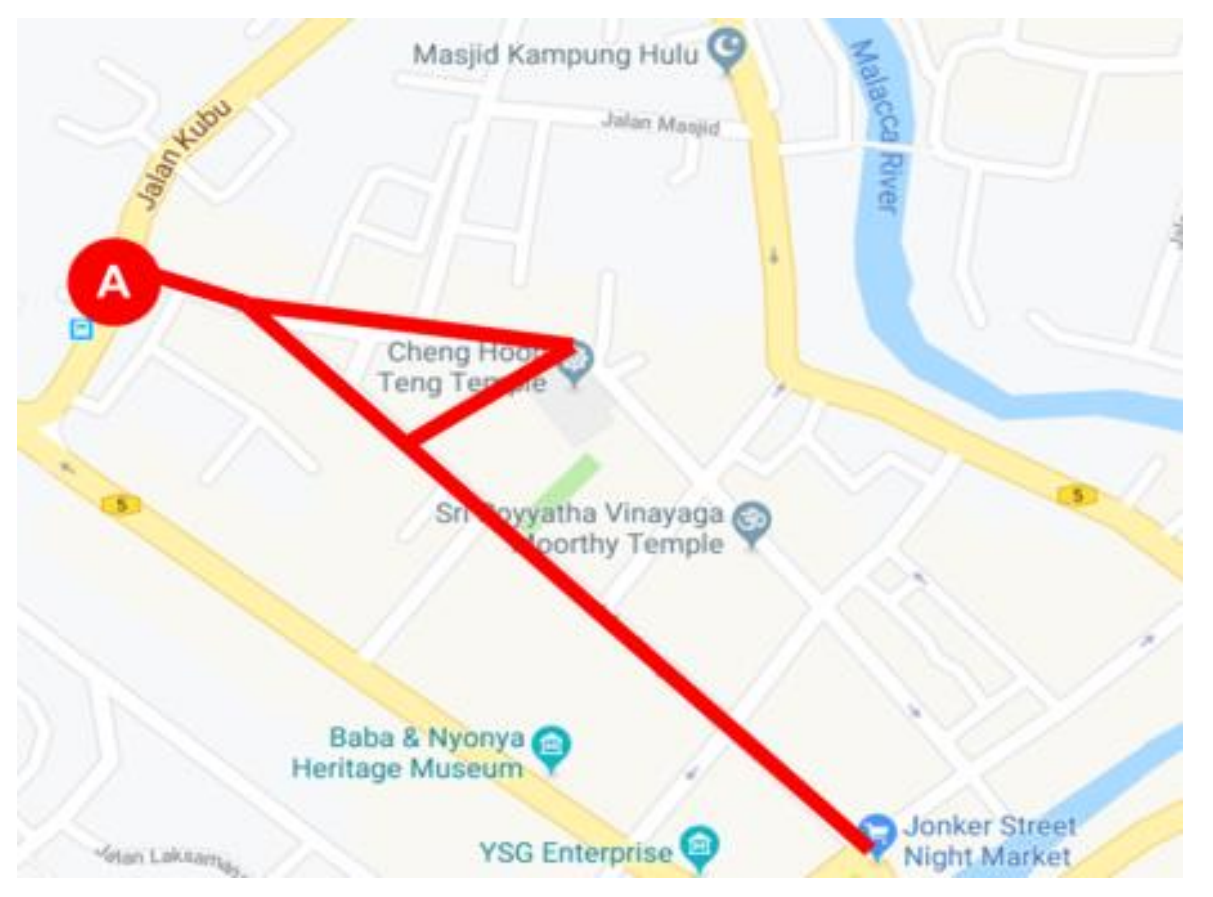

Figure 3: Layout of the Jonker Street food stalls area marked in red Source: Google Maps

The principal researcher was accompanied by an assistant for security reasons throughout the process. During this process, the principal researcher was part of the actual visitors to Jonker Street and have never been to this place before the data collection period. The huge crowd of visitors was overwhelming so body physical contact was inevitable. More, the source of light was not sufficient enough to light up the whole area. This situation raised a concern about personal safety while conducting data collection. For instance, pickpockets could be a concern to the principal researcher as she was carrying some valuable items meant for the research works. As the data was written down personally, the principal researcher would not be aware of her surrounding at all times. The presence of a personal assistant was to safeguard the safety of the principal researcher while completing the task.

For the data collection stage, each stall was observed individually and data were recorded manually. An identifier was given only to every food stall. Non-food stalls were counted in but unlabelled. Two types of profiles were identified: types of food sold and their prices. Most of the food stalls would have their menu and price tags. However, for stalls without price tags, a brief question was asked to the vendors: How much is this ....?. All data were written in a field notebook and safely kept until the data analyzing process.

The data analysis was initiated by cleaning the raw data first. Then, all data were tabulated in Microsoft Excel. Identifiers for each food stall were retained. Keywords were used to identify the types of food sold. Next, data were further categorized into three major themes: 1) food, 2) desserts/snacks, and 3) beverages. For price profile, similar food type was grouped and the price was classified from the lowest to the highest for that food item. At the final stage, results were reported in two main categories of subtopics: food profile and price profile. The details of the results were elaborated further in the next topic.

\section{Results and discussions}

A total of 230 stalls were observed and there were 134 food stalls. The results presented are based on the food stalls observed. The street food profiles are characterized into two major categories: 1) types of food sold and 2) range of prices.

\subsection{Food profile}

Each category is summarized in bar charts, as shown in Figure 4, Figure 5, and Figure 6. A comparison between contemporary and local foods is presented in Table 2. 


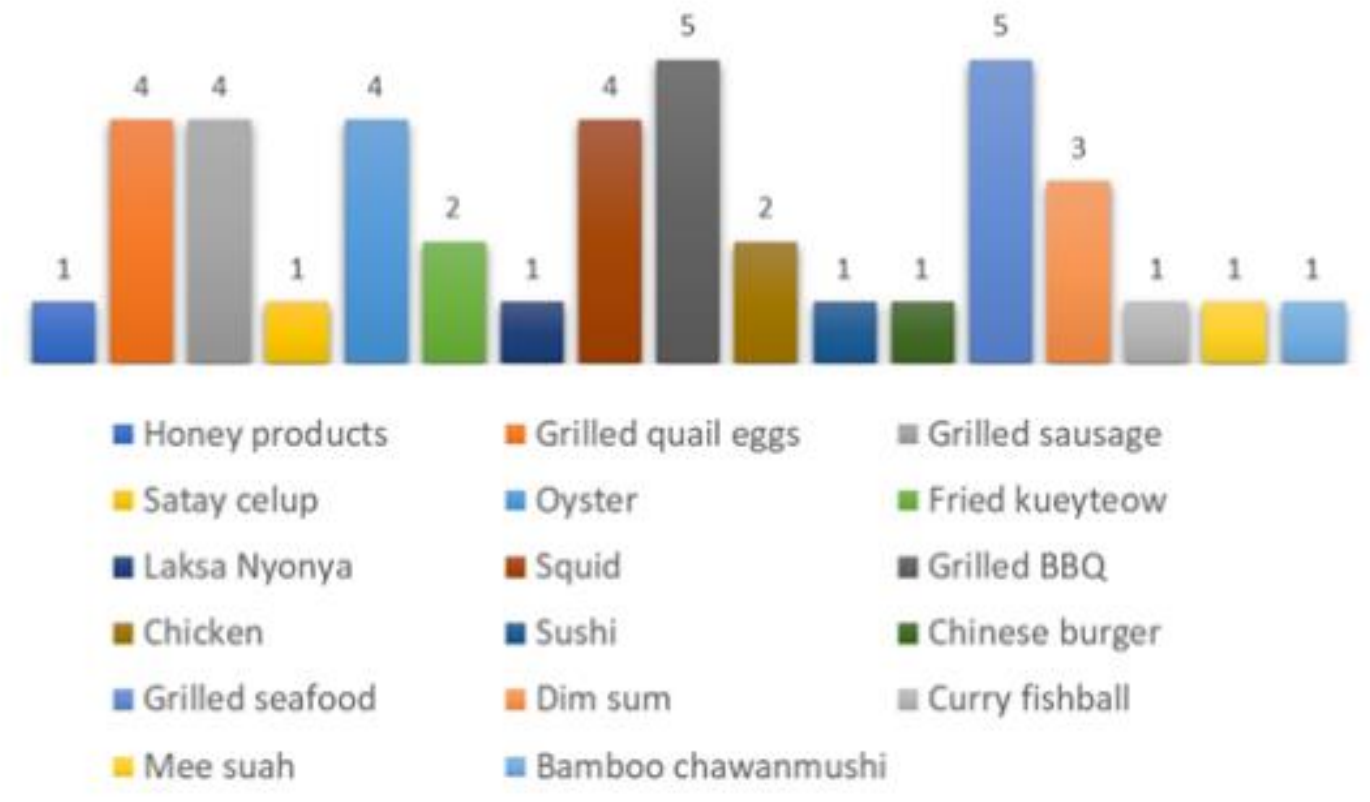

Figure 4: Types of food sold at Jonker Street

Notes: Specialties Oyster: fried oyster and oyster omelet; Chicken: salted egg chicken

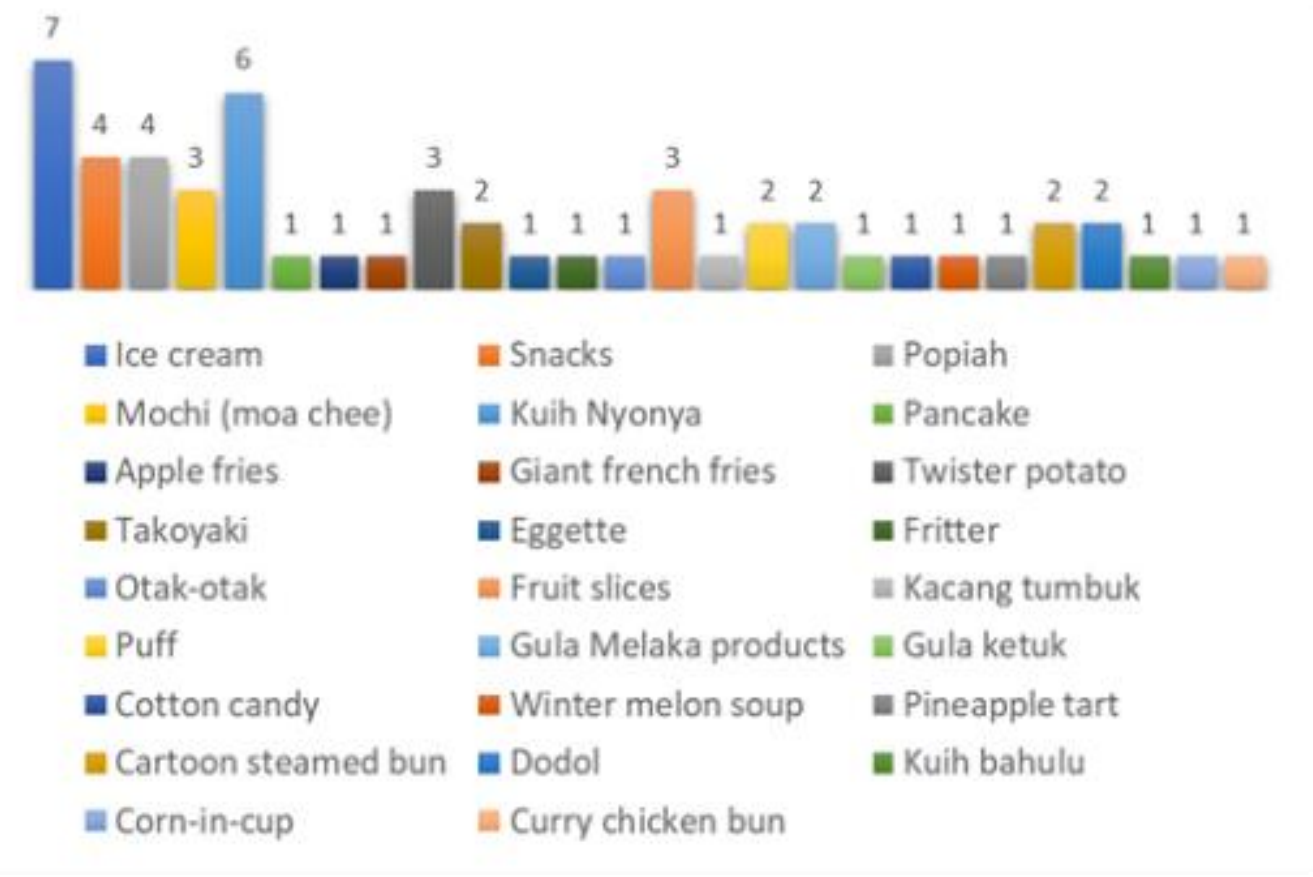

Figure 5: Types of desserts/snacks sold at Jonker Street

Notes: Specialties Ice cream: fried, durian, and yogurt; Snacks: chicken intestine, Taiwanese style, and dragon breath; Popiah: Japanese style 


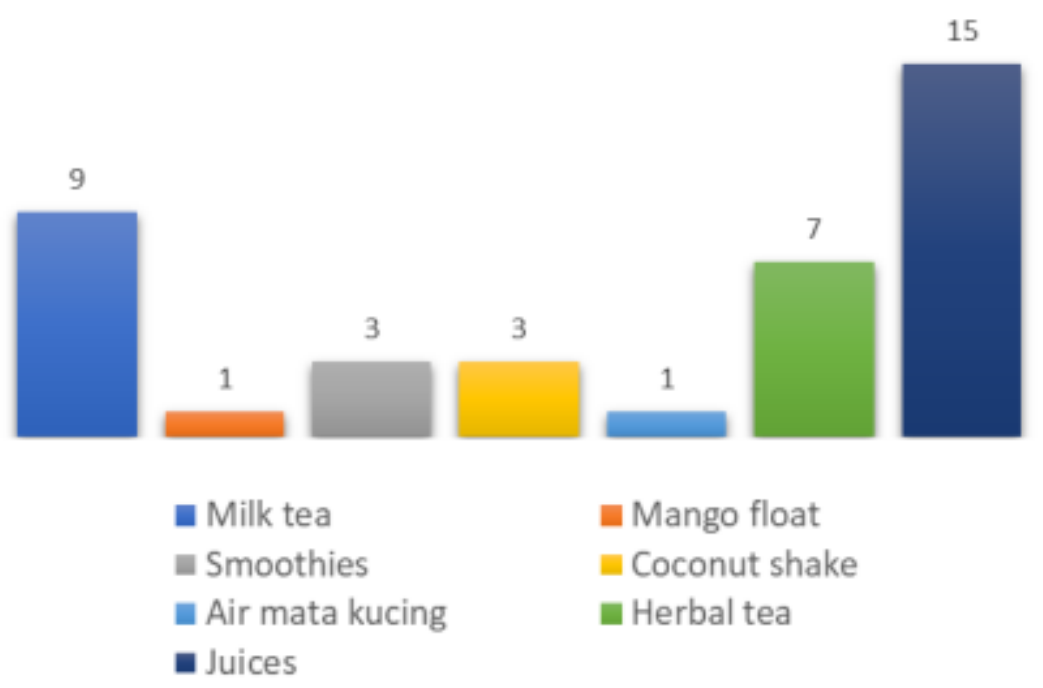

Figure 6: Types of beverages sold at Jonker Street

Notes: Specialties Juices: dragon fruit, melon, avocado, honeydew; Milk tea: Teh Harimau Melaka, Thailand style, Korean style, Japanese style

It should be highlighted that the actual names of the foods are retained to preserve the identity and origin of the foods. Under the food category, there were 10 grilled BBQ and grilled seafood stalls out of 41 food stalls. A total of 16 stalls sold grilled quail eggs, grilled sausage, oysters, and squid. Three stalls served Dim sum, whereas two stalls sold Fried kueyteow and chicken, respectively. For honey products, satay celup, Laksa Nyonya, Sushi, Chinese burger, Curry fishball, Mee suah, and Bamboo chawanmushi, there had been only one stall for each.

There were 54 stalls selling desserts and snacks. Most of the stalls offered one type of dessert or snack to make it unique compared to others. Ice cream has seven stalls followed by six Kuih Nyonya stalls. These Kuih Nyonya stalls offered one to five types of Kuih Nyonya such as Onde-onde, Kuih Talam, Pulut Inti, Bingka Ubi Kayu, Talam Gula Melaka, and Kuih Lopes. Contemporary desserts and snacks dominated Jonker Street, including pancake, apple fries, giant French fries, twister potato, takoyaki, mochi, eggette, puff, corn-in-cup, curry chicken bun, and cartoon-steamed bun. In total, there were 31 stalls with contemporary desserts and snacks compared to 23 stalls that offered local flavor.

Milk tea, also known as bubble tea or Boba milk tea has seen an increase in popularity worldwide. By taking this opportunity into a tourism attraction, nine stalls sold a variety of milk tea with pearl. Juices were the top one with 15 stalls selling various fruits and vegetable juices. Herbal tea derived from flowers, spices, and herbs was sold at seven stalls. These herbal teas were normally served hot and cold. Smoothies and coconut shake had six stalls overall: three stalls, respectively. Apparently, similar to food and desserts/snacks categories, the contemporary flavor of beverages was outshined the local flavor. A famous local drink, air mata kucing, was only available selling at one stall.

Table 2 shows a comparison between contemporary and local flavors for food, desserts/snacks, and beverages sold at Jonker Street. Under the food category, 24 types of contemporary food were sold compared to only 17 local dishes. International flavors from Taiwan, Hong Kong, China, Japanese, and Korea were dominating this segment. For desserts and snacks, contemporary food was made available from 31 stalls compared to only 23 stalls that sold local desserts and snacks. Under this classification, many products have international influences such as from Japan, Taiwan, Korea, Hong Kong, and Thailand. Interesting findings emerged in the beverages category where 31 stalls sold international flavored compared to eight stalls sold local drinks. It is not an exaggeration to say that local drinks, including Teh Tarik, Milo Ais, Nescafe variants, Kopi variants, and local fruit juices such as coconut, sugar cane, pineapple, and etc, could not be found along this street. Apparently, contemporary flavors are dominant over local flavors in all categories. 
Table 2: Comparison between contemporary and local flavors sold at Jonker Street

\begin{tabular}{|c|c|c|c|}
\hline Flavors & Types of Food, Desserts/Snacks and Beverages & No. of Stalls & Overall \\
\hline \multirow[t]{3}{*}{ Contemporary } & $\begin{array}{cl}\text { i. Food } & \\
- & \text { Grilled quail eggs, Grilled sausage, Oyster, } \\
& \text { Grilled BBQ, Sushi, Chinese burger, Dim } \\
& \text { sum, Mee suah, Bamboo chawanmushi }\end{array}$ & 24 & \\
\hline & $\begin{array}{l}\text { ii. Desserts/Snacks } \\
\text { - Ice cream, Snacks, Popiah (Japanese } \\
\text { style), Mochi (moa chee), Pancake, Apple } \\
\text { fries, Giant French fries, Twister potato, } \\
\text { Takoyaki, Eggette, Fritter, Puff, Cartoon } \\
\text { steamed bun, Corn-in-cup, Curry chicken } \\
\text { bun }\end{array}$ & 31 & 86 \\
\hline & $\begin{array}{l}\text { iii. Beverages } \\
\text { - Milk tea, Mango float, Smoothies, } \\
\text { Coconut shake, Juices }\end{array}$ & 31 & \\
\hline \multirow[t]{5}{*}{ Local } & $\begin{array}{cl}\text { i. Food } \\
\text { - } \\
\\
\text { kueyteow, Laksa Nyonya, Squid, Chicken, } \\
\text { Grilled seafood, Curry fishball }\end{array}$ & 17 & \\
\hline & $\begin{array}{l}\text { ii. Desserts/Snacks } \\
\text { - Popiah, Kuih Nyonya, Otak-otak, Fruit } \\
\text { slices, Kacang tumbuk, Gula Melaka } \\
\text { products, Gula ketuk, Cotton candy, } \\
\text { Winter melon soup, Pineapple tart, Dodol, } \\
\text { Kuih bahulu }\end{array}$ & 23 & \\
\hline & iii. Beverages & & 48 \\
\hline & - Air mata kucing, Herbal tea & 8 & \\
\hline & Total stalls & & 134 \\
\hline
\end{tabular}

The actual names of the foods collected in this study are retained to preserve the identity of the foods. Culinary and food culture can be derived from the preparation of foods, cooking methods, and ingredients used. The objectives in retaining all these components (preparation, cooking methods, and ingredients) are to resemble the authentic tastes as closely as possible to the original identity of the food. From the observation, many stalls displayed country origins of the food or beverages to attract the tourists' interest, for instance, Japanese style popiah, Chinese burger, Hong Kong fried oyster, just to name a few. On ingredients used, some stalls claimed (as stated on their signboards) that they used imported ingredients for the products sold. For example, mango juice used fresh mangoes imported from Thailand, pineapple juice and cuts used fresh pineapple imported from Thailand and Philippines, sushi used imported specialty rice from Japan and milk tea used imported ingredients from Taiwan and Hong Kong. Another component observed was the equipment and tools used in the preparation and storage of the food and beverages. It was obvious that all stalls which were selling international food and beverages have been using authentic cooking utensils for preparing and storing the food. For instance, the production of sushi involved a sushi knife and a bamboo rolling mat, mochi desserts used a wooden pounding tool (for both mallet and mortar), and grilled quail egg used a cast iron pan with cavities.

\subsection{Price profile}

The range of prices is classified into three categories: food, desserts/snacks, and beverages, as tabulated in Table 3, Table 4, and Table 5. Some stalls provided long tables and chairs for family or group dining. This type of stall was designated in the rear area of Jonker Street adjacent to the 
pedestrian walk. Each product is priced depending on the types of serving materials and sizes of serving. The serving ware was purposely used to serve the customers for a take-away or a brief dinein style. For instance, grilled sausage or grilled quail eggs were packed in small plastic bags for a handy hold. Hot food such as Laksa Nyonya or Fried kueyteow were served in disposable serve wares (bowl or plate) because the customers would enjoy the food by the stalls.

Table 3: Range of prices for food category

Types of Food

\section{Price}

$(\mathrm{RM}) /$ serving size

\begin{tabular}{lc}
\hline Honey products & $5-48 /$ jar \\
Grilled quail eggs & $4-11 /$ stick \\
Grilled sausage & $3-10 /$ each \\
Satay celup & $1 /$ each \\
Oyster & $6-10 / 100 \mathrm{gm}$ \\
Fried kueyteow & $5-7.50 /$ plate \\
Laksa Nyonya & $5-6 /$ bowl \\
Squid & $10-20 /$ each \\
Grilled BBQ & $4-11 /$ each \\
Chicken & $10-12 /$ piece \\
Sushi & $3-6 /$ each \\
Chinese burger & $10 /$ each \\
Grilled seafood & $10-48 / 100 \mathrm{gm}$ \\
Dim sum & $4-7 / 5$ pcs \\
Curry fishball & $4-6 /$ bowl \\
Mee suah & $8-10 /$ bowl \\
Bamboo chawanmushi & $12 /$ each \\
\hline
\end{tabular}

Table 4: Prices for desserts/snacks

Types of Price

Desserts/Snacks

(RM)/serving size

\begin{tabular}{lc}
\hline Ice cream & $2-7.50 /$ each \\
Snacks & $4-10 /$ each \\
Popiah & $2-6 /$ piece \\
Mochi (moa chee) & $4-5 /$ box \\
Kuih Nyonya & $0.50-6 /$ piece \\
Pancake & $7-8 /$ each \\
Apple fries & $7 /$ each \\
Giant French fries & $10 /$ box \\
Twister potato & $5-10 /$ each \\
Takoyaki & $5-11 /$ box \\
Eggette & $5-8 /$ each \\
Fritter & $3.5 /$ box \\
Otak-otak & $2-9 /$ piece \\
Fruit slices & $4-10 /$ slice \\
Kacang tumbuk & $3-5 /$ packet \\
Puff & $3-25 /$ box \\
Gula Melaka products & $12-15 /$ kg \\
Gula ketuk & $4 /$ packet \\
Cotton candy & $10-15 /$ packet \\
Winter melon soup & $5 /$ cup \\
Pineapple tart & $9 /$ box \\
Cartoon steamed bun & $4 /$ each \\
Dodol & $10-20 /$ packet \\
Kuih bahulu & $4-9 /$ box \\
Corn-in-cup & $4 /$ cup \\
Curry chicken bun & $25-35 /$ pc \\
& \\
&
\end{tabular}


Table 5: Prices for beverages

\begin{tabular}{lc}
\hline \multicolumn{1}{c}{ Types of Beverages } & Price (RM)/serving size \\
\hline Milk tea & $4-14 /$ cup \\
Mango float & $7-10 /$ cup \\
Smoothies & $10-12 /$ cup \\
Coconut shake & $5 /$ cup \\
Air mata kucing & $2 /$ cup \\
Herbal tea & $1.50-10 /$ cup \\
Juices & $2-12 /$ cup \\
\hline
\end{tabular}

Notes: Exchange rate 1 US Dollar $=4$ Ringgit Malaysia

From the observation, food and drinks sold in Jonker Street were pricey compared to other places. To compare, coconut shake special is priced at RM3.40 each at the Klebang Original Coconut Shake, a popular spot for coconut shake in Melaka but at Jonker Street, the same product (though different vendors) is sold at RM5 per cup. Another example, fruit slices are normally sold at RM1 for RM2 per slice at most eateries in Melaka. However, one slice of similar fruit cuts is sold at RM4 to RM10 at Jonker Street. The price difference is due to tourist location attracts more people and people are willing to spend more during their visit. In practice, most of the tourists are guided to visit Jonker Street by their tourist guides as they have signed up for vacation packages which include entry to interesting places and affordable accommodations. With restricted time spent at one location, tourists opt to buy items that are conveniently available and close to them. This scenario is a golden opportunity for food vendors to charge higher prices compared to other places.

It is worth noting that from the findings of this study, no authentic Malaysian local street food was found at Jonker Street. For instance, Nasi Lemak, a culinary icon of Malaysia, was not available at all. The unavailable menu list continues with Roti Canai, Mee Kari, Nasi Kerabu, Mee Goreng, etc.

\section{Conclusion}

In conclusion, contrary to the literature that food sold in local street food scenes represents local culture and identity, it is apparent that the street food sold at Jonker Street appears to adapt to the contemporary and trendy flavors to meet the tourists' demands. Literature also found that street foods are cheaply priced because they were prepared in poor condition, served in unattractive packaging, and used low-quality ingredients. The shift in flavors, presentations, and varieties of food offered is reflected in the pricing of the street food sold at Jonker Street. From the findings, Jonker Street, like most tourists' attraction spots in other places, plays a significant role as an agent of communication to promote numerous food and beverages; taking advantage of huge numbers of tourists flocking in Jonker Street annually that make it possible to promote the authentic Malaysian local food and beverages along with international cuisines.

This study offers several practical implications for the stakeholders in the tourism industry. As the contemporary flavor is prominent among food vendors, they can be agents for change in tourism to promote local food flavor because they can decide what to offer to the tourists. Next, the local authority could offer incentives to food vendors who sell local food. The local authority should begin government-led initiatives to boost food tourism. For example, by organizing an annual cooking local cuisine competition which could attract participation from around the world. Lastly, this study also highlights the power of social media marketing in promoting the local street food because many internet influencers were spotted making their contents at Jonker Street and some literature were referenced to their social media platforms as well.

\section{Limitations and study forward}

In this study, the limitations appeared in several aspects. First, this study was self-funded and this situation has caused financial constraints in expanding the scope of research. Next, because this study was self-funded, time was crucial in completing the research. The data collection process was 
completed within a few hours and it could be a threat to missing data. A longer time is needed to collect the data thoroughly. Third, the sample was restricted to Jonker Street food vendors only, therefore no generalization of street food in Melaka could be done. Some streets in Melaka that offer street food as tourist attractions as well. A future study could include those streets to make a meaningful representation of street food profiling, particularly in Melaka. This study employed an onsite observatory visit where the findings generated from the data could provide a baseline reference for future research. It is recommended that future study should look at tourists' opinions or preferences regarding street food sold at Jonker Street. A future study is crucial to understand the needs and demands from the tourists' perspectives as they are the primary stakeholders in the tourism industry. It is also suggested that future research could explore the demographics of street food vendors, the expectation of the tourists toward the street food sold at Jonker Street, and the economic impact of the street food to the local economy.

\section{Acknowledgment}

The author received no financial support for the research, authorship, and publication of this article.

\section{References}

Centre for the Promotions of Imports-European Union (2019). What are the opportunities for culinary tourism in Europe? https://www.cbi.eu/market-information/tourism/culinary-tourism/

Dahodwala, N. (2018, February 05). Traveloka blog: Street food at Jonker Night Market you'll regret not trying. https://blog.traveloka.com/en/see-and-do/jonker-night-market-street-food/

Data.gov.my (2017). Statistik kedatangan pelancong ke negeri Melaka. https://www.data.gov.my/data/ en_US/dataset/statistik-kedatangan-pelancong-ke-negeri-melaka -bagi-tahun-1999-2017

Dai, N., Zhong, T., \& Scott, S. (2019). From overt opposition to covert cooperation: Governance of street food vending in Nanjing, China. Urban Forum (pp. 1-20). Netherlands: Springer.

de Freitas, R. S. G., da Cunha, D. T., \& Stedefeldt, E. (2019). Food safety knowledge as gateway to cognitive illusions of food handlers and the different degrees of risk perception. Food Research International, 116, 126-134.

de Santana, G. R., \& Amparo-Santos, L. (2019). Institutionalization of street food in the modern urban space: Conformations, tensions and conflicts. Journal of Food and Nutrition Research, $7(6), 465-475$.

DeWaal, C. S., \& Rober, N. (2017). Global and local: Food safety around the world. http://safefoodinternational.org/local_global.pdf

Ellis, A., Park, E., Kim, S., \& Yeoman, I. (2018). What is food tourism?. Tourism Management, 68, 250-263.

Food and Agriculture Organization of the United Nations (2016). Food for the cities: Street food. www.fao.org/fcit/food-processing/street-foods/en/

Ghartey, A. F. Adu-Oppong, A., \& Doku, D. T. (2019). Personal hygiene practices of street-foodvendors in a rural district in Southern Ghana. Central Inquiry, 2(1), 107-131.

Global Data (2018). Key trends in culinary tourism. https://sector.tov.be/wp-content/uploads/2018 /11/GlobalData_Keytrendsin culinary tourism_130918.pdf

Henderson, J.C. (2014). Food and culture: In search of a Singapore cuisine. British Food Journal, $116(6), 904-917$.

Hill, J., Mchiza, Z., Puoane, T., \& Steyn, N. P. (2019). Food sold by street-food vendors in Cape Town and surrounding areas: A focus on food and nutrition knowledge as well as practices related to food preparation of street-food vendors. Journal of Hunger \& Environmental Nutrition, 14(3), 401-415.

Hotels.com (2019). 10 best things to do in Jonker Street. http://www.malacca.ws/malacca-top10s/top10-jonker-street-attractions.htm 
Isoni Auad, L., Cortez Ginani, V., dos Santos Leandro, E., Stedefeldt, E., Habu, S., Yoshio Nakano, E., Costa Santos Nunes, A., \& Puppin Zandonadi, R. (2019). Food trucks: Assessment of an evaluation instrument designed for the prevention of foodborne diseases. Nutrients, 11(2), 430.

Kocatepe, D., Keskin, İ., \& Kaya, Y. (2019). The effect of frying-the chemical microbiological, and acrylamide composition of mussels as a street food. Journal of Aquatic Food Product Technology, 28(1), 117-128.

Leong, M. D. (2015). 10 things to eat at Jonker Street night market, Melaka. Hungrygowhere. https://www.hungrygowhere.my/gallery/10-things-to-eat-at-jonker-night-market-melaka-* gid316e3101/

Letuka, P., Nkhebenyane, S., \& Thekisoe, O. (2019). Assessment of food safety knowledge, attitudes and practices among street food vendors and consumers' perceptions of street food vending in Maseru Lesotho. Europe PMC. https://doi.org/10.20944/preprints201905.0257.v1

Malaysia Tourism Promotion Board (2018). Malaysia tourists' profile 2018 by selected market. Retrieved from http://mytourismdata.tourism.gov.my/?page_id $=860$

McGuire, S. (2017). Food photo frenzy: Inside the instagram craze and travel trend. https://www.business.com/articles/food-photo-frenzy-inside-the-instagram-craze-and-travel trend/

Mnguni, E. M., \& Giampiccoli, A. (2016). Community-based tourism and food: Towards a relationship framework. African Journal of Hospitality, Tourism and Leisure, 5(1). ISSN:2223$814 \mathrm{X}$

Newman, G. E., \& Dhar, R. (2014). Authenticity is contagious: Brand essence and the original source of production. Journal of Marketing Research,51(3), 371-386. https://doi.org/10.1509/ jmr.11.0022

Nizame, F. A., Alam, M. U., Masud, A. A., Shoab, A. K., Opel, A., Islam, M. K., Luby, S.P., \& Unicomb, L. (2019). Hygiene in restaurants and among street food vendors in Bangladesh. The American Journal of Tropical Medicine and Hygiene. https://doi.org/10.4269/ajtmh.18-0896

Nwokorie, E. (2015). Food tourism in local economic development and national branding in Nigeria. SSRN Electronic Journal. 10.2139/ssrn.2770711.

Okumus, B., \& Sonmez, S. (2019). An analysis on current food regulations for and inspection challenges of street food: Case of Florida. Journal of Culinary Science \& Technology, 17(3), 209-223.

Oliveira, J. D. S. C., \& de São José, J. F. B. (2019). Food handling practices and microbial quality in street food. Journal of Food and Nutrition Research, 7(4), 319-324.

Privitera, D., \& Nesci, F. S. (2015). Globalization vs. local: The role of street food in the urban food system. Procedia Economics and Finance, 22, 716-722.

Rinaldi, C. (2017). Food and gastronomy for sustainable place development: A multidisciplinary analysis of different theoretical approaches. Sustainability, 9(10), 1748.

Rivera, L. (Feb 03, 2018). Why 2018 will be the year Street food gets a lot more sophisticated. Independence.https://www.independent.co.uk/life-style/food-and-drink/street-food-2018sophistication-why-kerb-club-mexicana-bao-pop-brixton-street-feast-a8186716.html

Saldana, J., \& Omasta, M. (2017). Qualitative research: Analyzing life. California, USA: Sage Publications, Inc.

Sarker, M. (2019). Consumer behavior on street food in Bangladesh. Dissertation. United International University. Retrieved from http://dspace.uiu.ac.bd/handle/52243/703

Shiningeni, D., Chimwamurombe, P., Shilangale, R., \& Misihairabgwi, J. (2019). Prevalence of pathogenic bacteria in street vended ready-to-eat meats in Windhoek, Namibia. Meat Science, $148,223-228$.

Tadesse, G., Mitiku, H., Teklemariam, Z., \& Marami, D. (2019). Salmonella and Shigella among asymptomatic street food vendors in the Dire Dawa city, Eastern Ethiopia: Prevalence, antimicrobial susceptibility pattern, and associated factors. Environmental Health Insights, 13, 1178630219853581. 
Traveloka (2018). Street food at Jonker Night Market you'll regret not trying. https://blog.traveloka.com/en/see-and-do/jonker-night-market-street-food/

TripAdvisor (2019). Things to do near Jonker Street. https://www.tripadvisor.com.my/Attractionsg306997-Activities-Melaka_Central Melaka_District_Melaka_State.html

Ukenna, S. I., \& Ayodele, A. A. (2019). Applying the extended theory of planned behavior to predict sustainable street food patronage in a developing economy. Journal of Food Products Marketing, 25(4), 404-434.

United Nation World Tourism Organization (2016). Global report on food tourism. http://www2.unwto.org/publication/unwto-am-report-vol-4-global-report-food-tourism

US Travel Association (2019). U. S. travel and tourism overview 2018. https://www.ustravel. org/system/files/media_root/document/Research_Fact-Sheet_US-Travel-and-TourismOverview.pdf

Veal, A. J. (2017). Research methods for leisure and tourism. $5^{\text {th }}$ eds. UK: Pearson.

World Food Travel Association (2016). 2016 Food travel monitor. https://www.worldfoodtravel. org/cpages/food-travel-monitor

World Food Travel Association (2019). What is food tourism? https://www.worldfoodtravel. org/cpages/what-is-food-tourism. 